\title{
Novel NAD(P)H oxidases in the cardiovascular system
}

\author{
K K Griendling
}

Heart 2004;90:491-493. doi: 10.1136/hrt.2003.029397

1 $\mathrm{n}$ the past 10 years, an enormous amount of research has focused on the role of $\mathrm{NAD}(\mathrm{P}) \mathrm{H}$ oxidases in cardiovascular physiology and pathophysiology. Initially, investigators characterised these enzyme activities biochemically and functionally, but more recently, the molecular identification of a family of Nox (NADPH oxidase) proteins related to the respiratory burst $\mathrm{NAD}(\mathrm{P}) \mathrm{H}$ oxidase of neutrophils has led to an explosion of information about expression patterns, regulation, and functional significance of these enzyme complexes. Nox enzymes have been found to be involved in the regulation of vascular tone, smooth muscle growth, inflammatory responses, and matrix metalloproteinase activity. They have been implicated in hypertension, atherosclerosis, heart failure, diabetic vascular disease, and restenosis. In this article, the current status of the molecular basis for and the functional consequences of activation of these novel enzymes will be discussed.

\section{NOX EXPRESSION IN THE CARDIOVASCULATURE}

The first Nox enzyme to be cloned and characterised was termed gp9lphox (or Nox2), because it is the catalytic unit of the phagocytic respiratory burst oxidase, which is important for non-specific host defence against invading microbes. This protein exists in a macromolecular complex with p22phox, another membrane subunit that stabilises gp9lphox and interacts with the cytosolic regulatory factor p47phox. p47phox has two tandem SH3 groups that interact with auto-inhibitory domains to maintain the protein in an inactive state. Upon phosphorylation of p47phox by protein kinase $\mathrm{C}$, this interaction is lost, and the SH3 groups and proline-rich tail are exposed and bind to the membrane subunits and a second regulatory cytosolic subunit, p67phox. p67phox, in turn, serves as a binding site for the small molecular weight $G$ protein Rac, which modulates enzyme activity. ${ }^{1}$

Originally, gp9lphox was thought to be restricted to phagocytic cells. Recent work, however, indicates that gp9lphox is expressed at low, but functionally important levels in many tissues. More importantly, in 1999, Noxl, the first of what is now a family of gp9lphox homologues, was discovered and shown to play a role in vascular smooth muscle cell (VSMC) growth. ${ }^{2}$ Since then, the Nox family has expanded to seven members: Noxl-5 and two longer homologues, Duoxl and Duox2, which have additional peroxidase domains. It is now clear that cardiovascular tissues express multiple Nox homologues (table 1), and that the complement of Nox enzymes varies not only among cell types, but also according to location in the vascular tree. For the most part, Nox expression has been reported at the mRNA level, and only minimal protein data are available, largely due to a dearth of available antibodies. Protein data will be critical for understanding the function and regulation of these enzymes.

With the discovery of gp9lphox homologues has come the finding that isoforms of regulatory subunits also exist. Newly identified homologues of p47phox (p4lnox or NOXOl, for nox organiser) and p67phox (p5lnox or NOXAl, for nox activator 1) apparently substitute for p47phox and p67phox in some cell types. ${ }^{3}{ }^{4}$ p4lnox has some constitutive activity and, unlike p47phox, it is not regulated by phosphorylation. p5 lnox binds both p4lnox and Rac. These two novel proteins can also interact with the classical phox proteins, lending an additional, complex mechanism of control to the $\mathrm{NAD}(\mathrm{P}) \mathrm{H}$ oxidases. Depending on the particular proteins expressed in a given cell, oxidase activity is likely to be uniquely regulated, making it imperative to study these proteins in individual tissues. Unfortunately, the role of these novel proteins in the cardiovascular system is completely unknown. Early studies suggest that they are not expressed in heart, but their existence in the vasculature has not been determined. This will be an important area for further investigation.

\section{FUNCTIONAL CONSEQUENCES OF NOX ACTIVATION}

Not only do cells and tissues express unique complements of Nox enzymes, but Nox proteins also appear to play distinct roles in different cell types. Our knowledge of the function of specific Nox enzymes is limited, largely because of the lack of specific animal models in which to test the roles of these proteins in the cardiovascular system. However, knockout mice lacking either gp9lphox or p47phox (gp9lphox-/- and p47phox-/- mice, respectively) have been used to advantage to study the (patho)physiological consequences of $\mathrm{NAD}(\mathrm{P}) \mathrm{H}$ oxidase activation.

In endothelium, adventitia, and cardiomyocytes, the agonist sensitive $\mathrm{NAD}(\mathrm{P}) \mathrm{H}$ oxidase appears to contain gp9lphox. Unlike the phagocytic oxidase, in endothelial cells at least, the gp9lphox-based oxidase is constitutively assembled in a perinuclear location associated with the cytoskeleton. ${ }^{5}$ It is, however, responsive to stimulation with angiotensin II, thrombin, and endothelin-l, as well as to mechanical forces. Superoxide and hydrogen peroxide produced by this enzyme regulate expression of various proinflammatory and proproliferative genes, including PAI-1, MCP-1, ICAM-1, and VEGF, ${ }^{6}$ and mediate fibroblast proliferation and connective tissue deposition. ${ }^{7}$ gp9lphox is also important in angiotensin II induced cardiomyocyte hypertrophy and collagen expression. ${ }^{8}$ Perhaps the most well known function of $\mathrm{NAD}(\mathrm{P}) \mathrm{H}$ oxidase derived superoxide is inactivation of nitric oxide to form peroxynitrite, leading to impaired endothelium dependent vasodilation and uncoupling of eNOS to produce additional superoxide. ${ }^{9}$ This scenario, where $\mathrm{NAD}(\mathrm{P}) \mathrm{H}$ oxidase derived superoxide activates other enzymes in turn to produce reactive oxygen species (ROS), may be a general mechanism for enhancing free radical formation, because it has recently been shown that $\mathrm{NAD}(\mathrm{P}) \mathrm{H}$ oxidases are upstream of activation of xanthine oxidase (which also generates ROS) by oscillatory shear stress. ${ }^{10}$

$\mathrm{NAD}(\mathrm{P}) \mathrm{H}$ oxidase activity in vascular smooth muscle has most often been linked to proliferation and migration. PDGF stimulated proliferation is mediated by a Noxl-containing oxidase, ${ }^{2}$ while PDGF induced migration is dependent upon an as yet unidentified Nox homologue. ROS derived from 
Table 1 Expression of Nox mRNAs in the cardiovasculature

\begin{tabular}{lllllll}
\hline & Nox1 & Nox2 & Nox3 & Nox4 & Nox5 & Duox 1 \\
\hline VSMCs from conduit vessels & + & - & - & +++ & $+^{*}$ & + \\
VSMCs from resistance vessels & - & + & ND & ND & ND & ND \\
EC & + & + & ND & +++ & $+^{*}$ & ND \\
Cardiac myocytes & ND & ++ & ND & + & ND & ND \\
Cardiac fibroblasts & + & + & ND & +++ & ND & ND \\
\hline *Human only. & & & & & \\
EC, endothelial cells; ND, not determined; VSMC, vascular smooth muscle cells. &
\end{tabular}

$\mathrm{NAD}(\mathrm{P}) \mathrm{H}$ oxidases also mediate inflammatory responses and macrophage infiltration into the media. ${ }^{11}$ Another major function of Nox derived ROS in smooth muscle is regulation of expression and activity of matrix metalloproteinases, enzymes that degrade the extracellular matrix and facilitate vessel remodelling. ${ }^{12}$

Virtually all cardiovascular cells express Nox4 to a much higher degree than either gp9lphox or Noxl (table 1). However, the function of Nox4 in these tissues has not been investigated. A clue to the function of Nox4 comes from overexpression experiments in NIH3T3 cells, in which Nox4 causes cellular senescence, ${ }^{13}$ suggesting that Nox4 may be antiproliferative. Consistent with this is the observation that Nox4 expression is increased by serum withdrawal and during smooth muscle redifferentiation following neointimal formation. ${ }^{14}$ The apparent opposing functions of Nox4 and other Nox enzymes raises the question of how enzymes that make the same product can regulate different intracellular functions. Possible explanations include highly restricted intracellular locations or differential coupling to agonists. In smooth muscle cells, Noxl is localised to caveolae, while Nox4 is found in focal adhesions, favouring the former explanation. ${ }^{15}$ There is also evidence to support the latter interpretation, since growth factors increase Noxl expression while downregulating Nox4 expression. ${ }^{16}$ Determining the true functions of Nox4 in the cardiovascular system awaits the development of appropriate antisense/siRNA techniques or transgenic and knockout animals.

\section{ROLE IN CARDIOVASCULAR DISEASE}

It has become abundantly clear that although $\mathrm{NAD}(\mathrm{P}) \mathrm{H}$ oxidases have a role in normal cardiovascular physiology, dysregulation of the Nox enzymes or inappropriate activation can contribute to the development of disease. In the vasculature, $\mathrm{NAD}(\mathrm{P}) \mathrm{H}$ oxidase activation has been strongly associated with hypertension (see review by Lassègue and colleagues ${ }^{17}$ ). In a recent elegant paper, Landmesser and colleagues showed that the angiotensin II induced increase in blood pressure was reduced in mice lacking $\mathrm{p} 47 \mathrm{phox}^{18}$ confirming earlier studies in which a role for $\mathrm{NAD}(\mathrm{P}) \mathrm{H}$ oxidases in hypertension was inferred. It remains to be determined which Nox enzymes are involved, because the regulation of specific Nox homologues by p47phox is not fully understood. gp9lphox, Nox4, and Duoxl have been shown to be expressed in human coronary atherosclerotic plaques, with gp9lphox abundantly expressed at the vulnerable shoulder region. ${ }^{19} 20$ The functional role of this family of enzymes in atherosclerosis is questionable, because knockout of gp9lphox appears to have little effect on lesion burden in ApoE-/- mice, but deletion of p47phox does reduce lesion area. ${ }^{21} 22$ p47phox is likely to regulate multiple Nox enzymes, suggesting that one of the novel $\mathrm{NAD}(\mathrm{P}) \mathrm{H}$ oxidases may be involved in atherogenesis. Finally, progression from left ventricular hypertrophy to heart failure is also accompanied by activation of $\mathrm{NAD}(\mathrm{P}) \mathrm{H}$ oxidases, ${ }^{23}$ but although activation of gp9lphox has been implicated in cardiac hypertrophy, it remains to be determined if other Nox enzymes are activated during heart failure.

\section{CONCLUSION}

Despite the potential importance of the Nox enzymes in cardiovascular physiology and pathophysiology, we are only in the early stages of understanding their myriad functions and mechanisms of regulation. Tremendous progress has been made in the few years since the discovery of the first gp9lphox homologue, but a clearer picture of the function of the Nox enzymes awaits the development of homologue specific transgenic and knockout animals. Given the intriguing results from in vitro experiments, it is likely that future animal experiments will validate a critical role for this novel enzyme family in normal cardiovascular function and disease.

\section{ACKNOWLEDGEMENTS}

The author's work is supported by NIH grants HL38206, HL58000, and HL58863. We thank Dr Bernard Lassègue for critically reading the manuscript.

Correspondence to: Dr Kathy K Griendling, Emory University, Division of Cardiology, 319 WMB, 1639 Pierce Drive, Atlanta, GA 30322, USA; kgriend@emory.edu

\section{REFERENCES}

1 Babior BM. NADPH oxidase: an update. Blood 1999;93:1464-76.

2 Suh Y, Arnold RS, Lassègue B, et al. Cell transformation by the superoxidegenerating oxidase mox1. Nature 1999:401:79-82.

3 Banfi B, Clark RA, Steger K, et al. Two novel proteins activate superoxide generation by the NADPH oxidase NOX1. J Biol Chem 2003;278:3510-13.

4 Takeya R, Ueno N, Kami K, et al. Novel human homologues of p47phox and p67phox participate in activation of superoxide-producing NADPH oxidases. $J$ Biol Chem 2003;278:25234-46.

5 Li JM, Shah AM. Intracellular localization and pre-assembly of the NADPH oxidase complex in cultured endothelial cells. J Biol Chem 2002;277: 19952-60

6 Griendling KK, Sorescu D, Lassègue B, et al. Modulation of protein kinase activity and gene expression by reactive oxygen species and their role in vascular physiology and pathophysiology. Arterioscler Thromb Vasc Biol 2000;20:2175-83.

7 Rey FE, Pagano PJ. The reactive adventitia: fibroblast oxidase in vascular function. Arterioscler Thromb Vasc Biol 2002;22:1962-71.

8 Bendall JK, Cave AC, Heymes C, et al. Pivotal role of a gp91 (phox)containing NADPH oxidase in angiotensin II-induced cardiac hypertrophy in mice. Circulation 2002;105:293-6.

9 Landmesser U, Dikalov S, Price SR, et al. Oxidation of tetrahydrobiopterin leads to uncoupling of endothelial cell nitric oxide synthase in hypertension. J Clin Invest 2003;111:1201-9.

10 McNally JS, Davis ME, Giddens DP, et al. Role of xanthine oxidoreductase and the $\mathrm{NAD}(\mathrm{P}) \mathrm{H}$ oxidase in endothelial superoxide production in response to oscillatory shear stress. Am J Physiol-Heart and Circ Physiol (in press.)

11 Liu J, Yang F, Yang XP, et al. NAD(P)H oxidase mediates angiotensin IIinduced vascular macrophage infiltration and medial hypertrophy. Arterioscler Thromb Vasc Biol 2003;23:776-82.

12 Galis ZS, Khatri JJ. Matrix metalloproteinases in vascular remodeling and atherogenesis: the good, the bad, and the ugly. Circ Res 2002;90:251-62.

13 Geiszt M, Kopp JB, Varnai $P$, et al. Identification of renox, an NAD(P)H oxidase in kidney. Proc Natl Acad Sci U S A 2000;97:8010-14.

14 Szöcs K, Lassegue B, Sorescu D, et al. Upregulation of Nox-based NAD(P)H oxidases in restenosis after carotid injury. Arterioscler Thromb Vasc Biol 2002;22:21-7

15 Hilenski LL, Clempus RE, Quimn MT, et al. Distinct subcellular localizations of nox 1 and nox4 in vascular smooth muscle cells. Arterioscler Thromb Vasc Biol (in press.) 
16 Lassègue B, Sorescu D, Szöcs K, et al. Novel gp9l phox homologues in vascular smooth muscle cells: nox1 mediates angiotensin II-induced superoxide formation and redox-sensitive signaling pathways. Circ Res $2001 ; 88: 888-94$.

17 Lassègue B, Clempus RE. Vascular NAD(P)H oxidases: specific features, expression, and regulation. Am J Physiol Regul Integr Comp Physiol 2003:285:R277-97.

18 Landmesser U, Cai H, Dikalov S, et al. Role of p47(phox) in vascular oxidative stress and hypertension caused by angiotensin II. Hypertension 2002:40:51 1-15.

19 Kalinina N, Agrotis A, Tararak E, et al. Cytochrome b558-dependent NAD(P)H oxidase-phox units in smooth muscle and macrophages of atherosclerotic lesions. Arterioscler Thromb Vasc Biol 2002;22:2037-43.
20 Sorescu D, Weiss D, Lassegue B, et al. Superoxide production and expression of nox family proteins in human atherosclerosis. Circulation 2002; 105: 1429-35.

21 Kirk EA, Dinaver MC, Rosen $\mathrm{H}$, et al. Impaired superoxide production due to a deficiency in phagocyte NADPH oxidase fails to inhibit atherosclerosis in mice. Arterioscler Thromb Vasc Biol 2000;20:1529-35.

22 Barry-Lane PA, Patterson C, van der Merwe $M$, et al. p47phox is required for atherosclerotic lesion progression in $\mathrm{ApoE}(-/-)$ mice. J Clin Invest 2001; 108:1513-22.

23 Li JM, Gall NP, Grieve DJ, et al. Activation of NADPH oxidase during progression of cardiac hypertrophy to failure. Hypertension 2002;40:477-84

\section{IMAGES IN CARDIOLOGY}

doi: $10.1136 /$ hrt.2003.026559

\section{Giant atrial septal aneurysm simulating a right atrial tumour}

$\Lambda$ 75 year old man was admitted to the hospital for elective coronary artery bypass grafting (CABG). He had a history of stable coronary artery disease for five years but he complained of angina at rest during the last two months. Coronary angiography revealed severe stenosis of the proximal left anterior descending artery, which was not suitable for angioplasty. He also had chronic atrial fibrillation, but was not receiving any anticoagulation. His medications were aspirin, $\beta$ blockers, and nitrates. Transthoracic echocardiography showed good left ventricular function with mild dilation of both atria. Before the CABG a transoesophageal probe was inserted for routine cardiac function evaluation. A large echogenic mass in the right atrium (panel A) and a secundum atrial septal defect with biphasic flow were
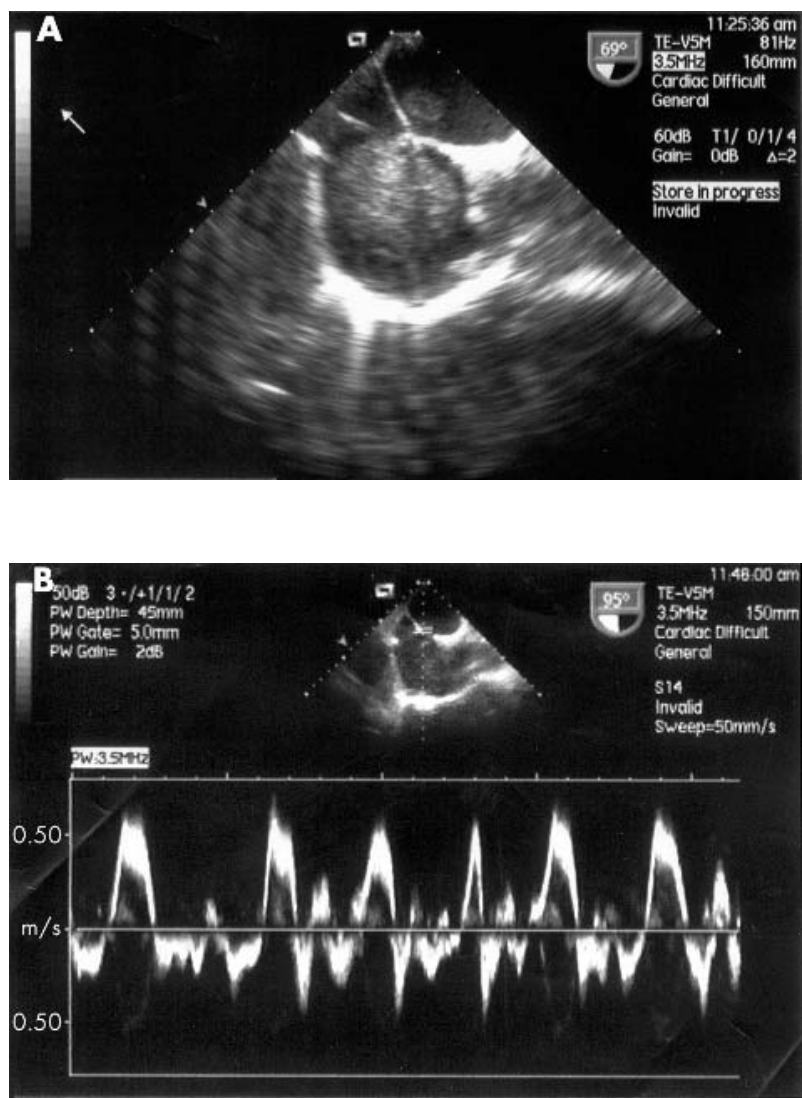

detected (panel B). The mass was at first thought to be a large thrombus or myxoma attached to the atrial septum. After bolus injection of normal saline in the right jugular vein, intra-atrial shunt was excluded (panel C) and a giant atrial septal aneurysm with automated contrast and low flow through the patent foramen ovale was revealed. The diagnosis was subsequently confirmed when the patient's blood pressure fell, the automated contrast disappeared, and the aneurysm wall was clearly seen (panel D). The aneurysm was resected and CABG was performed.

K D Pappas

E Arnaoutoglou

G Papadopoulos kopappas@cc.uoi.gr
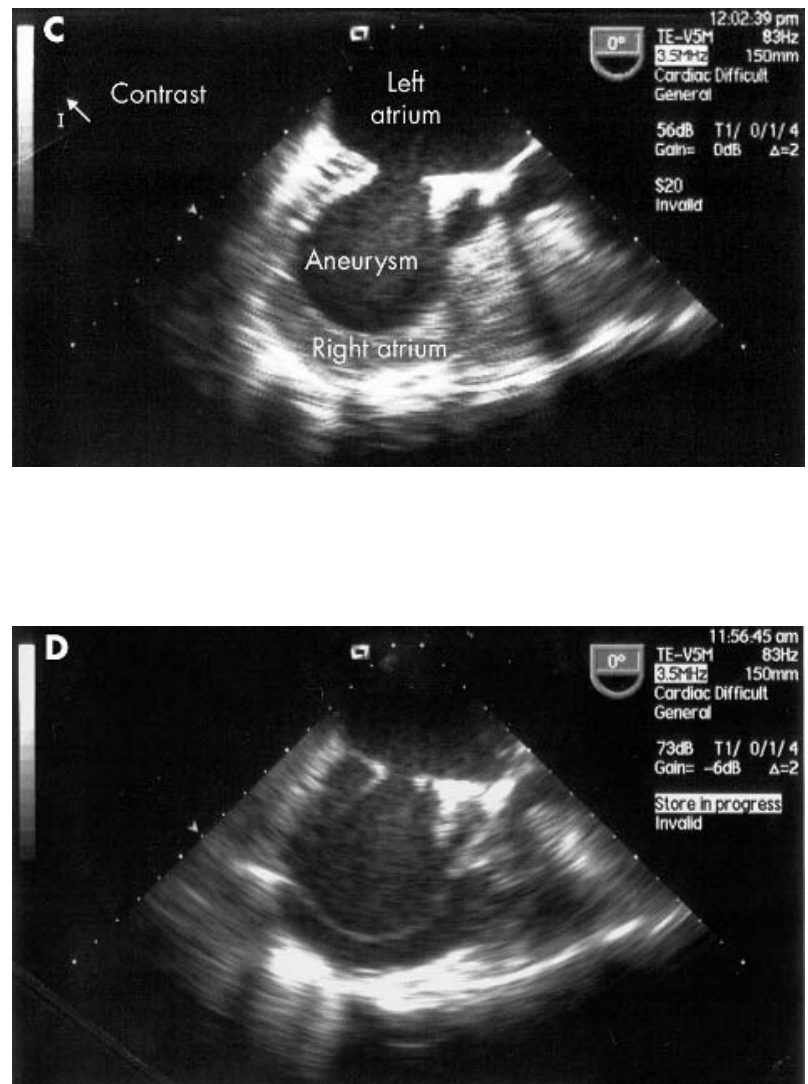